\title{
Vegetative morphology and interfire survival strategies in the Cape Fynbos grasses
}

\author{
H.P. LINDER* and R.P. ELLIS**
}

Keywords: Cape flora, ecology, fire, fynbos, growth form, habit, Poaceae, survival strategies

\section{ABSTRACT}

\begin{abstract}
It is shown that there is a wide range of structural variation in the habit of the Arundineae and Ehrharteae of the fynbos of the Cape Floristic Region (Cape Province, South Africa). Structural differences in the bases of the fynbos grasses have been classified into four groups: swollen, knotty tillering, weak and annual. Variation in the position of the innovation buds occurs with one group having basal perennating buds, implying that all the culm material is annual, while the second group has cauline innovation buds, leading to the development of a divaricate perennial herb. The recognition of caducous, mesic (orthophyllous) and sclerophyllous leaf blades is also possible, based on leaf morphology and anatomy. These variations in growth forms allow the classification of the Cape grasses into five guilds adapted for survival in the dense fynbos vegetation that develops between the well-spaced fires in these heathlands. The following guilds have been recognized: competition avoiders that grow on rock ledges and outcrops where competition from shrubby vegetation is reduced; reseeders, that survive the protracted interfire period as seed; geophytes, that survive this period as underground organs; coppicers, that survive as small plants; and competitors, that grow tall by means of cauline innovation buds, and so are able to compete with the shrubby heath vegetation.
\end{abstract}

\section{UITTREKSEL}

\begin{abstract}
Daar word aangetoon dat daar ' $n$ wye reeks strukturele variasie in die groeiwyse van die Arundineae en Ehrharteae van die fynbos van die Kaapse Floristiese Gebied (Kaapprovinsie, Suid-Afrika) bestaan. Strukturele verskille in die basisse van die fynbosgrasse is in vier tipes ingedeel: geswolle, knoesterig stingelsuiervormend, swak en eenjarig. Daar bestaan variasie in die posisie van die verjongingsknoppe, met een groep wat basale oorwinteringsknoppe het, wat impliseer dat al die halmmateriaal eenjarig is. Daarteenoor kom die verjongingsknoppe by die tweede groep op die stingel voor, wat aanleiding gee tot die ontwikkeling van 'n uitgespreide meerjarige kruid. Die erkenning van vroegafvallende, mesiese (ortofiele) en sklerofiele blaarskywe is ook moontlik, op grond van die blaarmorfologie en -anatomie. Die Kaapse grasse kan op grond van hierdie variasie in groeivorms in vyf gildes geklassifiseer word wat aangepas is om te oorleef in die digte fynbosplantegroei wat tussen die goedgespasieerde brande in hierdie heideveld ontwikkel. Die volgende gildes word erken: kompetisievermyders wat op rotslyste en klipriwwe groei waar kompetisie van struikagtige plantegroei verminder is; hersaaiers wat die langdurige periodes tussen brande as saad oorleef; geofiete wat hierdie periode in die vorm van ondergrondse organe oorleef; stomplootplante wat as klein plante oorleef; en kompeteerders wat deur middel van verjongingslote aan die stingels, hoog uitgroei en sodoende met die struikagtige fynbosplantegroei kan kompeteer.
\end{abstract}

\section{INTRODUCTION}

The southern and south-western parts of the Cape Province of South Africa possess a distinct flora, usually called the Cape Flora (Good 1974; Taylor 1978; Goldblatt 1978; Takhtajan 1986). Goldblatt (1978) delimited the geographical area of this flora, and called it the Cape Floristic Region, with the major vegetation type being 'fynbos'. This region is virtually synonymous with the Fynbos Biome (Rutherford \& Westfall 1986). This Cape Flora contrasts with the floras of adjacent biomes both in physiognomy and composition. Floristically, apart from the normally common Asteraceae and Fabaceae, it is characterized by the families Proteaceae, Ericaceae, Iridaceae and Restionaceae, with the Mesembryanthemaceae and Crassulaceae dominating in the more arid regions (Goldblatt 1978; Bond \& Goldblatt 1984). The levels of endemism are remarkably high, both at species $(68 \%)$ and at generic $(20 \%)$ level. The Poaceae, although generally ranking highly in most floras, is only the 13 th largest family in the Cape Floristic Region, even with the

* Bolus Herbarium, University of Cape Town, Rondebosch, 7700 .

** National Botanical Institute/Department of Agricultural Development, Private Bag X101, Pretoria 0001 .

MS. received: 1989.05 .18 . inclusion of the exotic pooids introduced from Europe (Bond \& Goldblatt 1984).

The Poaceae of the Cape Floristic Region are poorly understood taxonomically and ecologically. The last complete critical taxonomic revision was by Stapf (1899) for the Flora capensis, while Chippindall (1955) produced a guide to their identification. Conert $(1970,1971)$ revised the generic limits of Danthonia, which resulted in several neN genera being recognized for the region. Recently Gibbs Russell and Ellis (Gibbs Russell 1987a, b; Ellis 1987a,b; Gibbs Russell \& Ellis 1987, 1988) have started a programme on Ehrharta, and a co-ordinated programme on the arundinoid grasses of southern Africa is under way. Davidse and Ellis have worked on Tribolium and Prionanthium (Davidse 1988; Ellis 1989), Barker and Ellis on Pentameris and Pseudopentameris (Barker 1986; Ellis 1985a,b,c,d, 1986), while Linder \& Ellis (1990) have commenced a programme on Pentaschistis, Poagrostis and allied genera. Linder (in prep.) has reviewed the phytogeographical patterns inherent in the grasses of the Cape Floristic Region, showing that several taxa may help elucidate the origins and evolution of the Cape Flora. The distribution, breeding systems and eco-physiology of the Cape grasses have not been studied, and the only ecological information appears 
to be incidental comments in descriptions of vegetation types (i.e. Taylor 1978; Kruger 1979).

The Cape Floristic Region is ecologically very diverse. The climate is essentially Mediterranean, with most of the rain falling in winter, whereas the summers are dry. The amount and seasonal distribution of the precipitation is influenced greatly by the mountain ranges running more or less parallel to the coast. Along the coastal slopes the rainfall is about $1000 \mathrm{~mm}$ p.a., with the drier summers being ameliorated by mist and regular showers. The inland leeward slopes are much drier, with rainfall often less than $250 \mathrm{~mm}$ p.a., and with a very hot and dry summer (Fuggle \& Ashton 1979). The soils are generally deficient in nutrients, and the combination of dry summers and low soil nutrient status results in slow growth rates for the vegetation as a whole. The vegetation is a shrubland or heathland, from 0,5 to $3 \mathrm{~m}$ tall, with a very small herbaceous component, and virtually no annual component (Taylor 1978; Kruger 1979; Campbell 1985). Along the wet coastal ranges the vegetation is dense, with a high basal cover and no bare ground, while along the arid inland slopes the shrubs are well scattered, with ample bare ground which is colonized by annual plants after good winter rains. Although the fynbos vegetation is pyrophytic, fires are spaced well apart, with at least four years between fires, and at most about 40 years, due to the slow biomass build up. The modern average would probably be some 15 years between fires, although it appears likely that in the past the fire cycle could have been much longer (Van Wilgen 1987).

Habit and growth form in the Poaceae have received remarkably little attention in the literature, and consequently there is no generally useful terminology available to describe the vegetative structures. The terms 'tussock' and 'clump' refer to rather similar type structures, and some of the more curious, aerially branching plants have no ready terms. The Cape Poaceae show a remarkable diversity of habits, from the classical caespitose tussock grass to a complex growth form somewhat similar to a divaricate herbaceous plant. These habits appear to be adapted to a range of habitats, both spatial and temporal, in the Cape Floristic Region. They may be highly informative on the ecology and selective restraints operative in the area, and show that these grasses are closely integrated into this unique system, but they have received very little research attention.

Bond \& Goldblatt (1984) list almost 200 species of Poaceae for the Cape Floristic Region. Of these, virtually all the endemic species belong to the Arundinoideae in the tribes Arundineae and Ehrharteae. The Pooideae is represented largely by exotic taxa and the Bambusoideae is absent from this biome. Panicoideae and Chloridoideae, although present in fairly large numbers of individuals, have only one endemic species between them, and are scarce in 'typical' fynbos vegetation, but they tend to dominate the grassy fynbos types of the eastern Cape (Campbell 1985; Cowling 1984). The present study is based on the Arundineae, Ehrharteae and Pooideae, indigenous and largely endemic to the Cape Floristic Region. Nomenclature follows that of Gibbs Russell et al. (1985), except for Pentaschistis, where the nomenclature of Linder \& Ellis (1990) is followed.

\section{METHODS}

The distributions of the Poaceae species in the Cape Floristic Region were determined from herbarium records using the PRECIS system of the National Botanical Institute, Pretoria (Gibbs Russell 1985a), and the collections of the Bolus Herbarium, University of Cape Town. Whether these grasses were exotic or indigenous was determined following Gibbs Russell et al. (1985). Vegetative morphology was also examined on these herbarium specimens. The habit and growth forms of these grasses was classified by recognizing four different base types, two positions for the innovation buds and three different types of leaf morphology. This classification was tested during extensive field work in the spring and summer of 1987, and in the spring of 1988 (August December). While engaged in these field observations it became apparent that functional correlations exist between the vegetative morphology and the response of these fynbos grasses to fire, and more particularly, to the protracted periods without fire. These long interfire periods in the pyrophytic fynbos vegetation are unusual and the vegetative morphology, together with the fire history data for specific localities led to the recognition of several interfire period survival strategies exhibited by different fynbos grass species. Five different strategies were recognized and this classification was also tested in the field during this period.

Study sites are indicated on Figure 1. The age of the vegetation since the last fire was determined from records of the Chief Directorate of Nature Conservation, from records held in the local offices of Nature Conservation officials, from observations by mountaineers and farmers, and from personal experience of the post-fire successions.

Detailed leaf, culm and base anatomical studies were made from material freshly preserved in FAA in the field, and the vouchers are housed either at PRE (for leaf anatomy) or at BOL (for base and culm anatomy). The results on the anatomy of the bases and culms will be reported separately (Linder, Thompson \& Ellis in prep.). Many of the leaf anatomy results have already been published (Ellis 1980a,b, 1982a,b, 1985a-d, 1986, 1987a,b, 1988a,b), whereas studies on Pentaschistis leaf anatomy are in preparation (Ellis \& Linder in prep.).

Data for a comparison of the Poaceae growth forms of the Cape Floristic Region with those of other biomes was based on species lists available from Gibbs Russell, developed for the analyses of southern African flora and biomes (Gibbs Russell 1985b, 1987c). Growth forms of the savanna and grassland grass species were assigned on the basis of herbarium material. These results are summarized in Figure 2 and on p. 102.

\section{OBSERVATIONS AND DISCUSSION}

\section{Base morphology}

With the exception of the bamboos, most perennial grasses have herbaceous culms that die back to the base annually and are replaced by shoots arising from axillary basal buds (Gould 1968). The perennial grass 'plant' resulting from several seasons of growth is therefore, made up of several to many lateral shoots initiated at the base. 


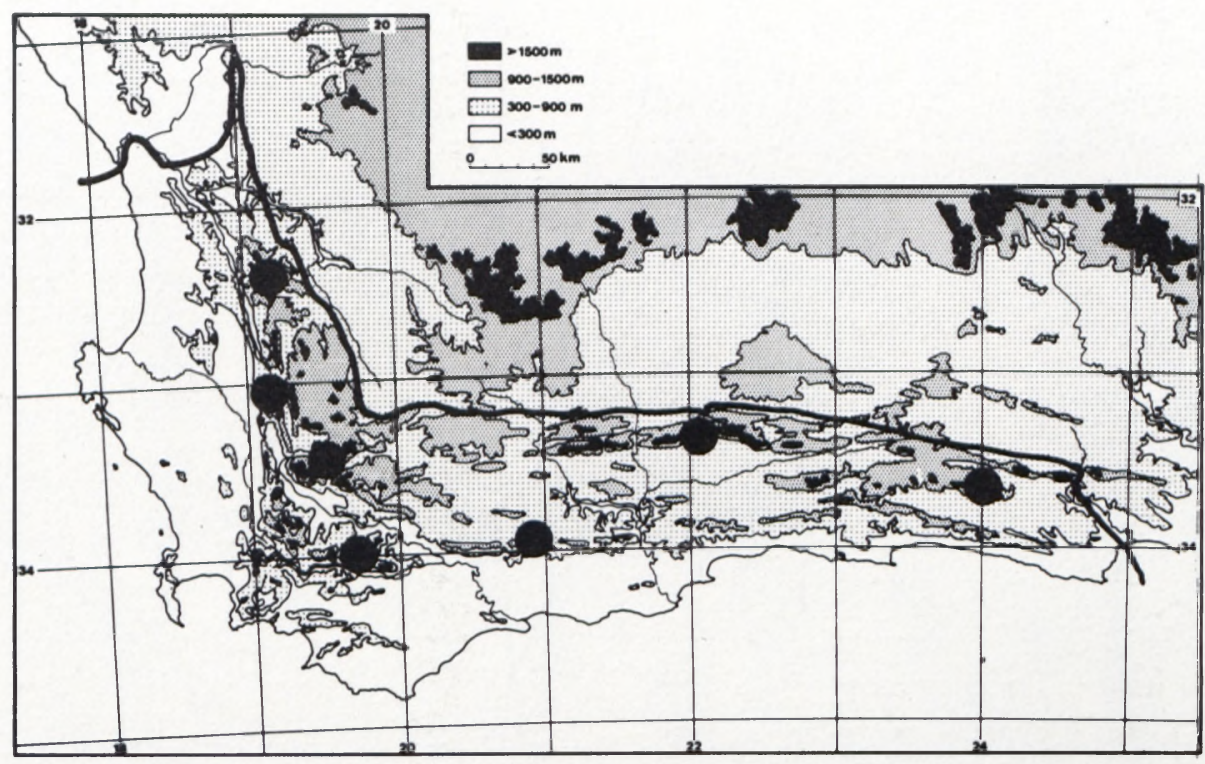

FIGURE 1. - The south-western Cape Province, South Africa. The Cape Floristic Region, as defined by Goldblatt (1978) is outlined by the line, while sample sites are indicated by the dots.

This results in the formation of clones which can reach a spread of $200 \mathrm{~m}$ as in Festuca rubra (Harberd 1961). By varying the length and thickness of the internodes of this basal portion of the culm, various structures can be developed. In the Cape grasses four different types of base can be distinguished (Figure 3).

\section{Bulbous or geophytic bases}

The base is modified into a distinct storage organ. This consists of the lowermost culm internode(s) which is generally swollen and tuberous, bulb- or corm-like, and which is usually covered by the fibrous bases of the old leaf sheaths (Burns 1946). The development of these bulbs and corms is rare in the Poaceae (Clayton \& Renvoize 1986; Watson \& Dallwitz 1988), and occurs in relatively few, unrelated species (Clark \& Fisher 1987). In the Cape arundinoids several different structures are found. Bulb-like structures, formed from swollen leaf bases,

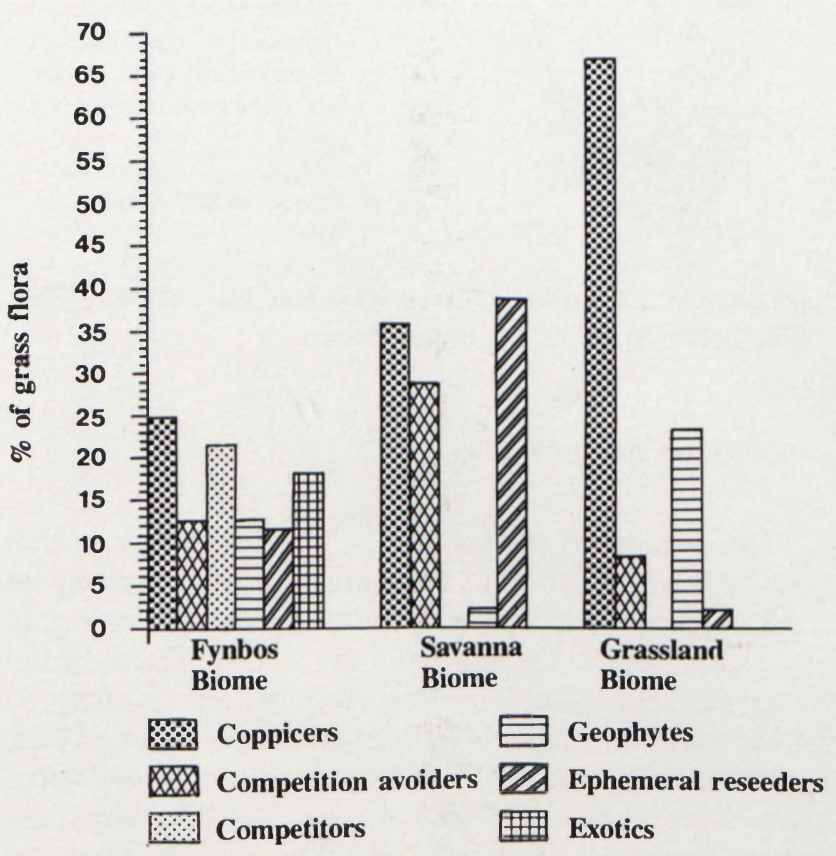

FIGURE 2. - Relative occurrence of growth forms of Poaceae in the Fynbos, Savanna and Grassland Biomes of southern Africa. occur in Pentaschistis viscidula, P. argentea, Merxmuellera rufa, and others. In Pentaschistis aristidoides a stout horizontal rhizome is formed, while in Ehrharta villosa portions of the stolons become swollen to form pseudobulb-like structures. These structures are deeply sunken below the level of the soil surface, and are often woolly from the densely hairy leaf sheaths, thus protecting the shoot bases from excessive evaporation or temperature changes (Tsvelev 1976). This could also be a protection against fire damage, or a defence against predators. Plants with these bases rarely form dense tufts, usually bearing a single terminal cluster of leaves and few fertile culms. Bulbous bases are unusually common in the Cape arundinoid grasses, examples being Merxmuellera rufa, M. decora, Ehrharta capensis, E. longifolia, E. dura, Pentaschistis aristidoides, $P$. viscidula, $P$ argentea and $P$. velutina in the Arundinoideae and Festuca scabra in the Pooideae.

\section{Knotty tillering bases}

The base consists of tightly aggregated clusters of very short internodes, positioned at or just below the soil surface. The whole structure is usually tangled with old leaf bases, which probably play a protective role for the basal buds. There is no clearly differentiated storage organ. The plants are capable of coppicing from this base after fire, and form tussocks (e.g. Pentaschistis pallescens, P. pyrophila and Merxmuellera arundinacea). If the tillering base is underground, the resulting tussock is often tightly caespitose, as in $P$. eriostoma, $P$. pyrophila and Merxmuellera stricta.

\section{Weak bases}

In this category only a few perennial culms arise from a basal node. The basal internode(s) is not swollen into storage organs, but sometimes associated swollen rhizomes occur (e.g. Ehrharta setacea and E. villosa). The plants developed from weak bases are usually loosely tufted, short-lived perennials, with branching culms which are decumbent at the base. This stooling (Gould 1968) gives a 'cushion' type of growth. Selected examples of this type of base are Pentaschistis pallida form B, P densifolia, 


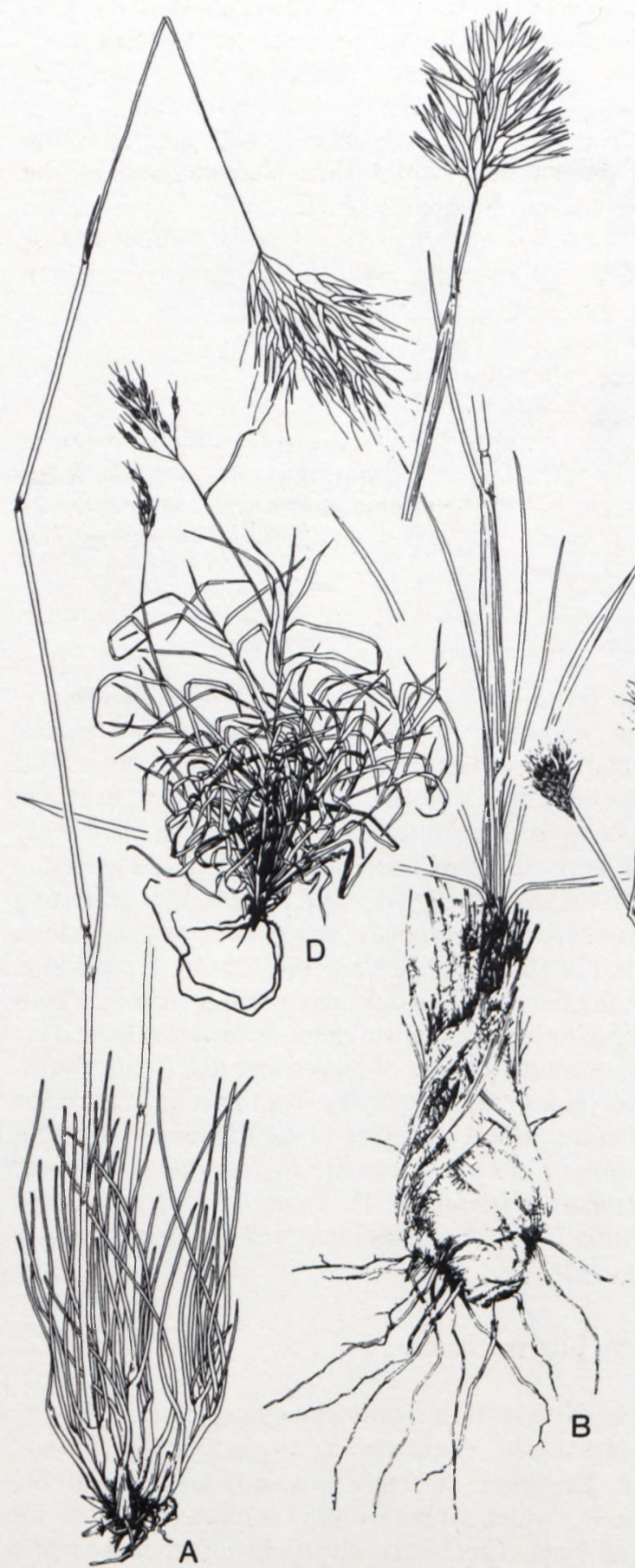

$P$. rosea subsp. rosea, $P$ alticola, $P$. aspera, $P$. acinosa, Ehrharta rupestris and $E$. setacea. These weak bases are very similar to annual bases in that the rooting system is weak, and no thickened woody structures are found.

\section{Annual bases}

In grasses with annual bases the primary shoot arises directly from the base, and few lateral innovation shoots develop further up the culms. The base never becomes woody. Annual grasses are rare in the mountains on the most nutrient-poor soils (Kruger 1979), but are better diversified on the arid margins of the Cape Floristic Region (Pentaschistis airoides subsp. airoides, $P$. aristifolia, $P$. capillaris, Urochlaena pusilla, Ehrharta brevifolia and $E$. pusilla). Biennials and triennials are found in the mountains. These also have the annual type of base

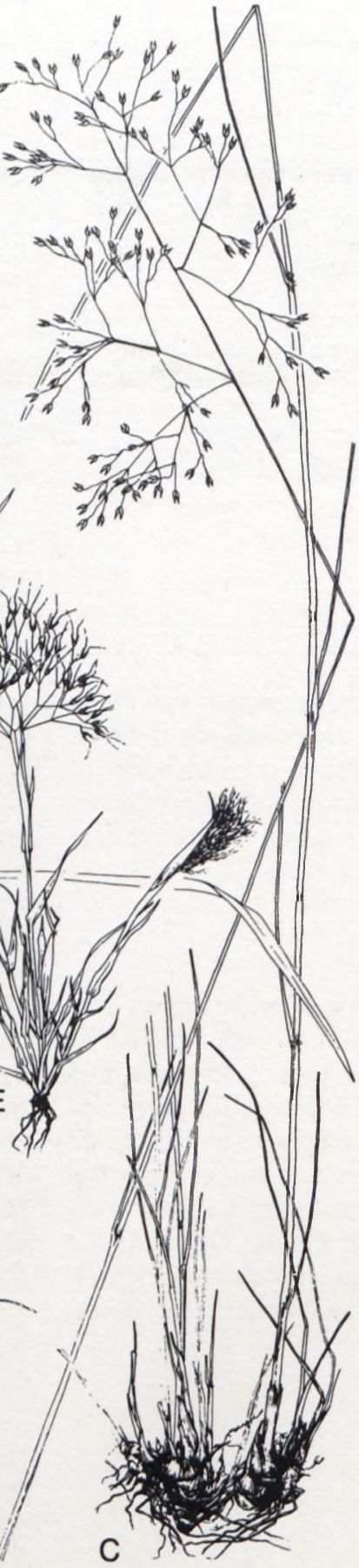

FIGURE 3.-Variation in the base structures of the fynbos arundinoid grasses. A, knotty tillering base, Pentaschistis pyrophila; B, geophytic base, Merxmuellera rufa; $\mathrm{C}$, disclike tillering base, Pentaschistis ampla; D, weak base, $P$. densifolia; E, annual base, $P$. airoides subsp. airoides. All $\times$ 0,4 .

(Pentaschistis rosea, P. pseudopallescens), showing the link between these and weak bases.

\section{Innovation bud position}

The culm is the axis on which the inflorescence as well as the leaves are borne. Each culm is terminated by an inflorescence, and the next season's growth is produced by lateral shoots arising from the nodes. These lateral shoots develop from innovation buds, which are enclosed and protected by the prophyll, a two-keeled modified leaf, which is located adaxially at the base of each lateral shoot (Clark \& Fisher 1987). Different growth habits are determined by the position of these perennating buds and their resultant lateral shoots. Two basic variants can be recognized (Figure 4). 


\section{Basal innovation shoots}

Basal innovation shoots develop from buds at the base of the plant. These produce culms which are annual, dying back to the upper tillering node after completion of flowering. All internodes above this node perish, and those below are persistent. This is the common situation in grasses (Gould 1968; Tsvelev 1976), and this tillering produces erect or decumbent lateral culms and the caespitose habit, usually as a result of intravaginal branching. After flowering the culms and leaves senesce, and are eventually replaced by a new basal innovation shoot. These basal innovation shoots are usually associated with knotty tillering bases. Plants with bulbous bases also innovate from the base, but these are deeply subterranean.

Grasses with this type of lateral shoot innovation essentially have an annual above-ground component.
Although generally grass leaves senesce after only a few months, many of the Cape grasses have leaves that persist for at least a year. The underground parts are strongly perennial, and may continue to grow for many years, reaching ages of up to 1000 years in Festuca ovina (Harberd 1962). This type of growth form is well adapted to the regular annual or biennial fires characteristic of the subtropical savannas and grasslands. In the Cape Floristic Region examples of this growth form are Pentaschistis glandulosa, P. pyrophila, Ehrharta calycina, and the species listed as having bulbous bases.

\section{Cauline innovation shoots}

Cauline innovation shoots are produced from nodes higher upon the culms. These culms are generally longlived, and the above-ground component is perennial, resulting in an 'evergreen' plant. This is an unusual

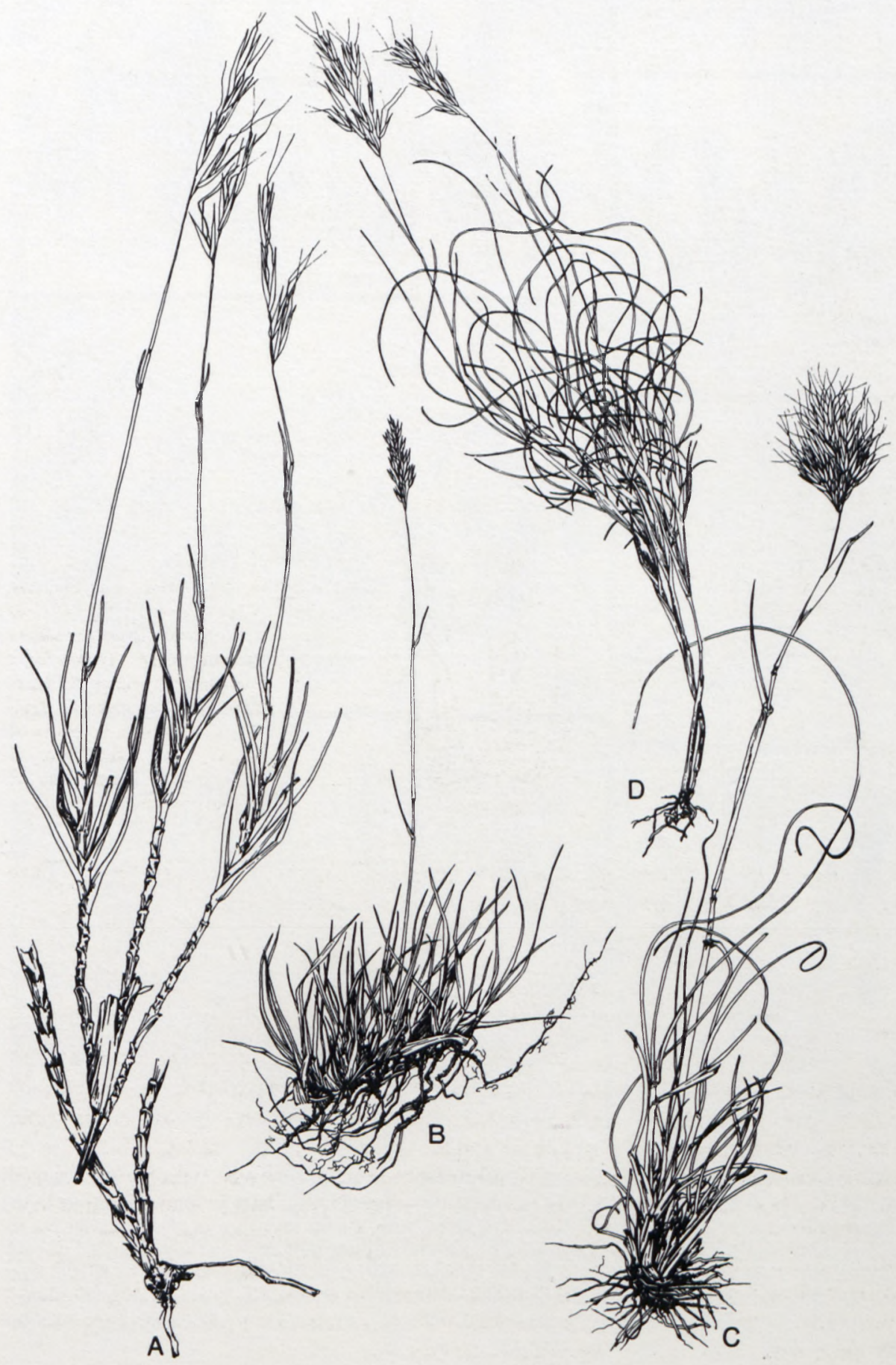

FIGURE 4. - Variation in the position of the innovation buds in the fynbos arundinoid grasses. A, caulescent innovation buds in a 'competitor', Pentameris squarrosa; B, basal innovation buds along creeping rhizomes, Pentaschistis galpinii; $\mathrm{C}$, basal innovation buds, forming a caespitose plant, Pentaschistis curvifolia; $\mathrm{D}$, innovation buds at the ends of thin erect culms, in an old plant of Pentaschistis colorata, forming a cushion. All $\times 0,4$. 


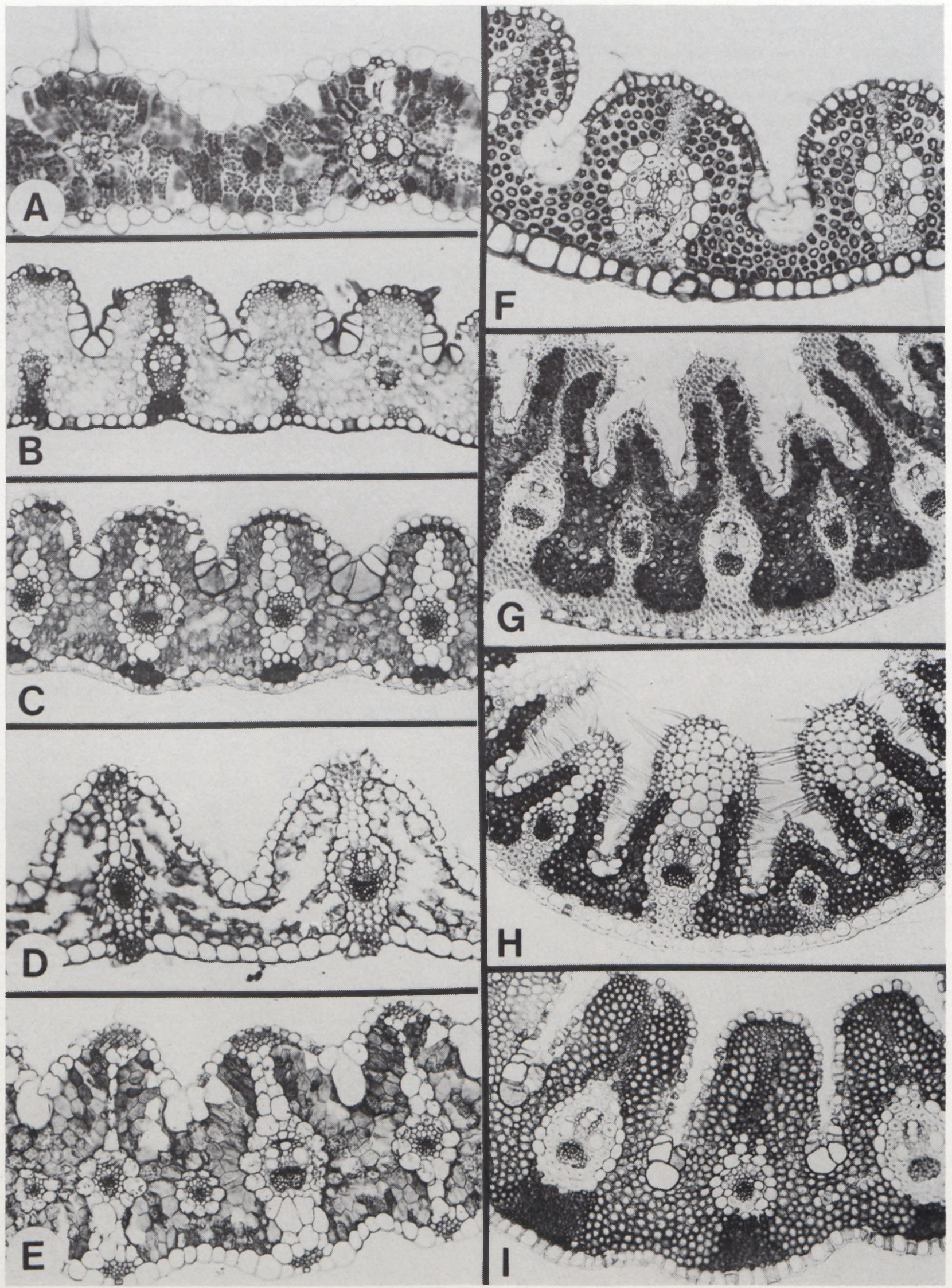

FIGURE 5. - Transverse sections of the leaves of the fynbos arundinoid grasses, illustrating variation in leaf type. A-E, mesic or orthophyllous leaf type; F-I, sclerophyllous leaf type. A, Ehrharta brevifolia, with large chlorenchyma cells and intercellular air spaces; B, Pentaschistis papillosa, with discrete sclerenchyma girders and strands; C, Tribolium uniolae, chlorenchyma cells relatively large and angular but air spaces reduced, intermediate type; D, Festuca scabra, typical pooid mesic anatomy with very diffuse mesophyll and widely spaced vascular bundles; E, Chaetobromus involucratus, mesic leaf anatomy; F, Ehrharta setacea, compact mesophyll of isodiametric cells; G, Pentaschistis eriostoma, compact mesophyll, bundles close together and continuous hypodermal sclerenchyma; H, Pentameris macrocalycina, compact mesophyll of small cells and few intercellular air spaces, sclerenchyma girders well developed; I, Merxmuellera rufa, compact sclerenchyma typical of sclerophyllous leaf type. All $\times 250$. 
situation in herbaceous grasses (Gould 1968). Branching culms are very rare in the Pooideae, but there are exceptions in the Andropogoneae (Clayton \& Renvoize 1986), Paniceae and particularly the woody Bambuseae (Roshevits 1937). The branching may be profuse with secondary and even tertiary branches. The bases of the species with cauline innovation shoots are either of the weak or of the knotty tillering type. These species also appear to be able to innovate from the base, and so survive fires by coppicing.

Three different patterns appear to occur in the cauline innovating species. In one group, the culms are more or less erect, and the branches well spaced. This results in a 'divaricate herb', which might function in allowing the plant to grow taller than species with only basal innovation shoots (i.e. Pentaschistis aspera, $P$ acinosa, $P$ scandens, Pseudopentameris macrantha, $P$. brachyphylla, Pentameris thuarii and $P$. squarrosa). In the second group the culms are more or less decumbent (at least at the base), and the branches mostly occur near the base of the culms. These plants develop into cushions, often low on the ground. Good Cape examples of this are Pentaschistis densifolia, $P$. rosea subsp. purpurascens and $P$. alticola. In the third group the plant is initially caespitose, with basal innovation shoots. As the plant becomes older, the innovation shoots are found further from the base of the plant, and a distinct, and sometimes quite long, stem section is found between the woody rootstock and the branching system. This transforms the plant from caespitose to tangled. This pattern is shown most clearly by $P$. colorata, but is also seen in Cape plants of the widespread Themeda triandra.

\section{Leaf morphology}

The leaf anatomy and morphology of grasses is very important taxonomically, but ecologically three leaf forms may be distinguished in the Cape Floristic Region (Figure 5).

\section{Caducous leaf blades}

In some species of Ehrharta the leaf blade is either early deciduous, or is represented by a small mucro at the apex of the sheath. The leaf sheaths are generally well developed, and together with the culms constitute the photosynthetic organs of the plants. These suffrutescent species are remarkable structural mimics of the Restionaceae.

\section{Sclerophyllous leaves}

Sclerophyllous leaves (Ellis 1988a) persist for more than one growing season, and possibly even for several years. These are tough, leathery leaves, typically permanently inrolled and filiform or acicular with no abaxial stomata and very compact mesophyll of small isodiametric chlorenchyma cells with minute intercellular air spaces. Sclerenchyma tissue is abundant and may be either lignified or with cellulose walls (Figure $5 \mathrm{~F}-\mathrm{I}$ ). This type of leaf appears to be analogous to the sclerophyllous leaves which are characteristic of the vegetation of the Cape Floristic Region, particularly with vegetation growing on the nutrient-deficient sands of the mountains. This type of blade structure probably helps to 'safeguard' the scarce nutrient resources. All species of Merxmuellera and Pentameris, as well as many species of Pentaschistis have this type of blade.

\section{Mesic leaves}

Mesic leaves do not persist for more than one growing season. They are typically soft and expanded with abaxial stomata and diffuse mesophyll, and with an extensive air space system. Sclerenchyma tissue is only associated with the vascular bundles as strands or girders (Figure 5A-E). This leaf type is common on soils with better nutrient status. The pooid exotics all have mesic type leaves, and indigenous taxa with mesic leaves (e.g. Chaetobromus and Tribolium) are lowland taxa associated with intermediate nutrient status soils. However, many species of Pentaschistis with mesic leaves are widespread in the Cape mountains. These mesic leaves of the Cape fynbos grasses appear to be analogous to the 'orthophyllous leaves' of Campbell (1985) although the first term refers to habitat and the second to the texture of the leaves.

\section{Interfire survival strategies}

The vegetation of the Cape is a shrubby heathland, dominated by Restionaceae, Ericaceae and Proteaceae (Taylor 1978). These fynbos plants are evergreen, generally highly divaricated, and they form a relatively dense shrubbery of $1-3 \mathrm{~m}$ tall. The vegetation burns on a variable cycle of between four and 40 years, as vegetation less than four years old rarely has adequate fuel to burn (Van Wilgen 1987). Grasses in general are well adapted to withstand fire, and tropical grasses in particular, become moribund if not burnt regularly. These tropical grasses generally are subject to annual, biennial or triennial fires and their growth forms and habits undoubtedly are determined largely by this regular incidence of fire.

Ecological studies on the vegetation of the Cape Floristic Region have generally emphasized the various methods by which the flora survives the sporadic fynbos fires (e.g. Manders \& Cunliffe 1987). However, in the case of the grasses, in addition to surviving the fires themselves, survival in the dense, shrubby fynbos vegetation that develops during the long interfire periods appears to be a major constraint. Immediately after fire, perennial grasses generally are an important component of the regenerating fynbos vegetation, even though this family is virtually absent in mature fynbos prior to burning. After a burn the vegetation gradually becomes denser, generally passing through dominance by the Restionaceae, then the Ericaceae, and finally the Proteaceae (Kruger 1977). This mature, dense vegetation excludes herbaceous species, and so also the grasses. There appear to be five ways in which the grass species of the Cape have responded to this situation.

\section{Competition avoiders (Table 1)}

These species exploit habitats where taller woody plants cannot grow. Such habitats are either in streams, or in rock crevices and ledges. In these harsh conditions the grasses compete with mosses, a few herbaceous evergreen species and geophytic orchids. The protection from fire offered by these habitats appears to be incidental. Some species are totally restricted to these habitats (e.g. Pentaschistis 
TABLE 1. - Distribution of growth form and survival strategy in the competition avoider Cape grasses. The vegetation types are approximate and follow Moll et al.(1984)

\begin{tabular}{|c|c|c|c|c|}
\hline Species & Base type & $\begin{array}{l}\text { Innovation } \\
\text { buds/shoots }\end{array}$ & Leaf type & Habitat \\
\hline $\begin{array}{l}\text { Pentaschistis } \\
\text { rigidissima } \\
\text { acinosa }\end{array}$ & \multirow{3}{*}{$\begin{array}{l}\text { weak; } \\
\text { forming low } \\
\text { cushions }\end{array}$} & \multirow{2}{*}{ cauline } & \multirow{3}{*}{ sclerophyllous } & $\begin{array}{c}\text { Mesic } \\
\text { Mountain Fynbos, } \\
\text { cliffs and ledges }\end{array}$ \\
\hline $\begin{array}{l}\text { Pentaschistis } \\
\text { capensis }\end{array}$ & & & & $\begin{array}{l}\text { Lower altitudes } \\
\text { in streams and } \\
\text { waterfalls }\end{array}$ \\
\hline $\begin{array}{l}\text { Pentaschistis } \\
\text { malouinensis }\end{array}$ & & basal & & $\begin{array}{c}\text { Mesic } \\
\text { Mountain Fynbos }\end{array}$ \\
\hline $\begin{array}{l}\text { Pentaschistis } \\
\text { aspera } \\
\text { papillosa }\end{array}$ & weak & $\begin{array}{l}\text { cauline } \\
\text { only }\end{array}$ & \multirow[b]{2}{*}{ mesic } & $\begin{array}{c}\text { Mesic } \\
\text { Mountain Fynbos, } \\
\text { low altitude }\end{array}$ \\
\hline $\begin{array}{l}\text { Pentaschistis } \\
\text { densifolia } \\
\text { pusilla } \\
\text { Anthoxanthum } \\
\text { dregeanum } \\
\text { tongo } \\
\text { Brachypodium } \\
\text { distachyon }\end{array}$ & $\begin{array}{l}\text { weak; } \\
\text { often with } \\
\text { rhizomes }\end{array}$ & $\begin{array}{l}\text { basal and } \\
\text { cauline }\end{array}$ & & $\begin{array}{c}\text { Mesic } \\
\text { Mountain Fynbos }\end{array}$ \\
\hline $\begin{array}{c}\text { Pentaschistis } \\
\text { eriostoma }\end{array}$ & tillering & cauline & sclerophyllous & variable \\
\hline
\end{tabular}

rigidissima, $P$. acinosa). Other species colonize soil exposed after fire, but soon succumb to the rapidly growing shrubby vegetation. Pentaschistis densifolia, $P$. malouinensis, and often $P$. eriostoma fall into the latter category.

Typically, the avoiders are short, cushion forming plants with weak bases, cauline innovation shoots, and sclerophyllous leaves. They are generally restricted to higher altitudes in the mountains (possibly because of the availability of crevices). Pentaschistis eriostoma and $P$. malouinensis are both rather widespread, and ecologically flexible. $P$. eriostoma, in particular, can vary from a typical vegetation avoider at higher altitudes, to a classical tussock grass on the arid fringes of the Cape Flora. Some vegetation avoiders deviate from the above description by the possession of mesic leaves, and often also basal innovation shoots. Pentaschistis densifolia and $P$. pusilla are arundinoid examples, while most of the 'avoider' pooids also fall into this category (Anthoxanthum dregeanum, A. tongo and Brachypodium distachyon).

The only true graminoid hydrophyte in the Cape is Pentaschistis capensis which is found over a wide altitude range, but always growing on rocks and stones in perennial streams, often draped over waterfalls. For this species it is then not clear whether it is avoiding drought or competition from woody vegetation.

\section{Reseeders (Table 2)}

This group can be defined as those taxa that survive the interfire period as seed. The seed germinates after fire and grows into annual or short-lived perennial plants that survive for 1-3 years before being forced out by the recovering fynbos vegetation. The grass plants die, leaving their seed till the next fire, which may not be for 25 years, and possibly longer. Whether the species survive as seed banks, or whether they depend on regular dispersal is not clear. If they survive as seed banks, the mechanisms by which the seed is protected for such an extensive period requires attention.

Within the Cape Floristic Region several different reseeder strategies exist. True annuals (ephemerals) are found only on the arid fringes of the Region. This includes the West Coast Strandveld (Moll et al. 1984) and the Succulent Karoo (Acocks 1988). In these vegetation types soil nutrient levels are higher, but low rainfall prevents the development of a dense basal cover, so that there is ample open ground between the scattered bushes, where annual grasses can grow following adequate rainfall. Pentaschistis airoides subsp. airoides, $P$. aristifolia, $P$. capillaris, Urochlaena pusilla, Stipa capensis, Ehrharta brevifolia, E. longiflora, E. pusilla, Tribolium utriculosa and T. echinata are annual arundinoid species of these arid regions. This is possibly the closest analogue to the true Mediterranean conditions of southern Europe and northern Africa to be found in the winter rainfall region of the Cape. These are not strictly postfire annuals and usually function as interfire annuals as well.

Fynbos postfire reseeders are not true annuals, in that they do not germinate annually, although the plants themselves only grow for a single growing season. Pentaschistis pseudopallescens, $P$. rosea and possibly 
$P$. alticola are biennial or triennial, which flower in the second year after fire. They occur above $1000 \mathrm{~m}$ on nutrient-poor and leached soils in the western Cape mountains, and it is possible that these slow development times may be due to the poor soil nutrient status, and the harsh growing conditions. $P$. pallida form B and $P$. triseta are reseeders which flower in the first year and are found at lower altitudes, in warmer conditions, and on less leached soils. Both groups appear to be facultative perennials, depending on the severity of the summer droughts. If the plant survives the summer, and is not shaded out by the growing vegetation, it may flower for a second year. These species may totally dominate the vegetation after the fires. They all have weak or annual bases, basal innovation shoots and mesic leaves.

\section{Geophytes (Table 3)}

This group of species behaves like typical geophytes, appearing early in the first winter or spring after fire and flowering profusely soon after commencing growth. By the second post-fire season they are not as rominent and flower less profusely. When they become overshaded by the regenerating woody vegetation, they appear to survive the protracted interfire period by means of their swollen, subterranean storage organs. It appears as if flowering depletes the base, but that subsequent photosynthesis may replenish the storage products (Hodgkinson \& Williams 1983). However, research is still required to follow the cycle of flowering and photosynthate accumulation and translocation, both in these grasses and in analogous groups, such as Watsonia in the Iridaceae. The factors controlling flowering and dormancy are not understood. The stored products allow the plants to flower almost immediately after fire, while the reseeders apparently have to spend the first year accumulating sufficient reserves to support a flowering episode.

The Cape flora is remarkably rich in geophytic grasses. These species tend to dominate areas that are frequently burnt or bush-cut, like fire-breaks. This survival strategy is undoubtedly effective and the methods of overcoming damage by herbivores are poorly understood. These geophytic grasses are probably an important food source for mole-rats, a possibility which needs to be investigated (Lovegrove \& Jarvis 1986). Examples are Pentaschistis viscidula, $P$. argentea, $P$ velutina, Merxmuellera rufa, $M$. decora and Ehrharta longifolia. Morphologically, they all have bulbous, subterranean bases, basal innovation shoots and sclerophyllous leaf blades, although these leaves are unusual in having abaxial stomata. Pentaschistis aristidoides probably also belongs to this group, but is unusual in that the base is developed as a rhizome. Ehrharta dura, E. microlaena, E. capensis and Festuca scabra differ from the typical type described above by their mesic leaf anatomy.

\section{Coppicers (Table 4 )}

These species survive the interfire period as persistent, almost dormant, moribund plants. After a fire, they coppice from the base and then flower late in the first spring or summer. The plants then persist above ground without, or with very little, subsequent flowering. They are often evident in the mature vegetation, persisting in the vegetative state as weak moribund tussocks. Presumably, if the interfire period is too long, the plants will eventually die. This form is then usually found at higher

TABLE 2. - Distribution of growth form and survival strategy in the ephemeral reseeder Cape grasses. The vegetation types are approximate and follow Moll et al.(1984)

\begin{tabular}{|c|c|c|c|c|}
\hline Species & Base type & $\begin{array}{c}\text { Innovation } \\
\text { buds/shoots }\end{array}$ & Leaf type & Habitat \\
\hline $\begin{array}{l}\text { Pentaschistis } \\
\text { triseta }\end{array}$ & $\begin{array}{l}\text { annual; } \\
\text { true annual }\end{array}$ & basal & & \\
\hline $\begin{array}{l}\text { Pentaschistis } \\
\text { pallida form B } \\
\text { barbata }\end{array}$ & $\begin{array}{c}\text { weak; } \\
\text { short-lived } \\
\text { perennials }\end{array}$ & \multirow[b]{3}{*}{$\begin{array}{l}\text { basal and } \\
\text { cauline }\end{array}$} & mesic & Lowland Fynbos \\
\hline $\begin{array}{l}\text { Pentaschistis } \\
\text { rosea } \\
\text { pseudopallescens } \\
\text { pungens }\end{array}$ & $\begin{array}{l}\text { weak; } \\
\text { biennials and } \\
\text { short-lived } \\
\text { perennials }\end{array}$ & & $\begin{array}{c}\text { mesic to } \\
\text { intermediate }\end{array}$ & $\begin{array}{c}\text { Mesic } \\
\text { Mountain Fynbos }\end{array}$ \\
\hline $\begin{array}{l}\text { Pentaschistis } \\
\text { airoides subsp. airoides } \\
\text { aristifolia } \\
\text { capillaris } \\
\text { Ehrharta } \\
\text { brevifolia } \\
\text { delicatula } \\
\text { longiflora } \\
\text { pusilla } \\
\text { triandra } \\
\text { Tribolium } \\
\text { echinata } \\
\text { utriculosa } \\
\text { Urochlaena } \\
\text { pusilla }\end{array}$ & $\begin{array}{c}\text { annual; } \\
\text { true ephemerals }\end{array}$ & & mesic & $\begin{array}{c}\text { Succulent Karoo } \\
\text { and Strandveld }\end{array}$ \\
\hline
\end{tabular}


TABLE 3. - Distribution of growth form and survival strategy in the geophytic Cape grasses. The vegetation types are approximate and follow Moll et al.(1984)

\begin{tabular}{|c|c|c|c|c|}
\hline Species & Base type & $\begin{array}{l}\text { Innovation } \\
\text { buds/shoots }\end{array}$ & Leaf type & Habitat \\
\hline $\begin{array}{l}\text { Pentaschistis } \\
\text { aristidoides } \\
\text { argentea } \\
\text { velutina } \\
\text { viscidula } \\
\text { Merxmuellera } \\
\text { decora } \\
\text { lupulina } \\
\text { rufa } \\
\text { Ehrharta } \\
\text { longifolia }\end{array}$ & \multirow{3}{*}{$\begin{array}{l}\text { bulbous; } \\
\text { corms }\end{array}$} & \multirow{3}{*}{ basal } & $\begin{array}{l}\text { sclerophyllous; } \\
\text { with abaxial } \\
\text { stomata }\end{array}$ & \multirow[t]{2}{*}{$\begin{array}{c}\text { Mesic } \\
\text { Mountain Fynbos }\end{array}$} \\
\hline $\begin{array}{l}\text { Ehrharta } \\
\text { dura } \\
\text { microlaena }\end{array}$ & & & \multirow{2}{*}{ mesic } & \\
\hline $\begin{array}{l}\text { Ehrharta } \\
\text { capensis } \\
\text { melicoides } \\
\text { Festuca } \\
\text { scabra }\end{array}$ & & & & $\begin{array}{l}\text { Mountain Fynbos, } \\
\text { lower altitudes }\end{array}$ \\
\hline
\end{tabular}

TABLE 4. - Distribution of growth form and survival strategy in the coppicing Cape grasses. The vegetation types are approximate and follow Moll et al.(1984)

\begin{tabular}{|c|c|c|c|c|}
\hline Species & Base type & $\begin{array}{l}\text { Innovation } \\
\text { buds/shoots }\end{array}$ & Leaf type & Habitat \\
\hline $\begin{array}{l}\text { Pentaschistis } \\
\text { colorata } \\
\text { tortuosa } \\
\text { eriostoma } \\
\text { ampla } \\
\text { Pentameris } \\
\text { macrocalycina } \\
\text { dregeana } \\
\text { obtusifolia }\end{array}$ & \multirow[t]{2}{*}{ tillering } & cauline & \multirow[t]{3}{*}{ sclerophyllous } & \multirow{4}{*}{$\begin{array}{c}\text { Mesic } \\
\text { Mountain Fynbos }\end{array}$} \\
\hline $\begin{array}{l}\text { Pentaschistis } \\
\text { pyrophila }\end{array}$ & & \multirow{6}{*}{ basal } & & \\
\hline $\begin{array}{l}\text { Pentaschistis } \\
\text { curvifolia } \\
\text { malouinensis }\end{array}$ & \multirow{4}{*}{ weak } & & & \\
\hline $\begin{array}{l}\text { Ehrharta } \\
\text { calycina } \\
\text { Pentaschistis } \\
\text { rupestris } \\
\text { glandulosa }\end{array}$ & & & \multirow{3}{*}{ mesic } & \\
\hline $\begin{array}{l}\text { Pentaschistis } \\
\text { pallida form } F \\
\text { tomentella }\end{array}$ & & & & $\begin{array}{c}\text { Dry } \\
\text { Mountain Fynbos }\end{array}$ \\
\hline $\begin{array}{l}\text { Pentaschistis } \\
\text { cirrhulosa } \\
\text { calcicola }\end{array}$ & & & & $\begin{array}{c}\text { Elim } \\
\text { Limestone } \\
\text { Fynbos }\end{array}$ \\
\hline $\begin{array}{l}\text { Merxmuellera } \\
\text { arundinacea } \\
\text { dura } \\
\text { cincta } \\
\text { stricta }\end{array}$ & tillering & & sclerophyllous & Renosterveld \\
\hline
\end{tabular}


altitudes where the mature vegetation is not very dense, and where recovery rates are slower.

Pentaschistis pyrophila and Pentameris obtusifolia are typical examples utilizing this survival strategy. They have knotty tillering bases, basal innovation shoots and sclerophyllous leaf anatomy. Other species which utilize this strategy, but not exclusively so, are Pentaschistis colorata, $P$. tortuosa, $P$ eriostoma and $P$. ampla. Pentaschistis curvifolia, $P$ malouinensis and Ehrharta calycina may also best be placed into this group, despite their weak bases.

This group overlaps to some extent ivith other strategies, and is often difficult to define. Many species that form large, persistent tussocks in the more open vegetation at lower altitudes are probably best placed into this group, despite the absence of direct evidence of coppicing after fire. This would include Pentaschistis rupestris, $P$ pallida form F, $P$. glandulosa, $P$ tomentella, $P$. cirrhulosa, $P$. calcicola, Merxmuellera arundinacea and $M$. cincta. These lower altitude species are generally not shaded out during the interfire period, but this is because of the sparse vegetation in which they grow, rather than any special morphological adaptations that they may have.

\section{Competitors (Table 5)}

This small, specialized group of grasses appears to be able to compete with low mature fynbos. The plants have branching culms capable of almost indefinite growth. After flowering has terminated the growth of a culm, a lateral branch continues growth from an upper leaf innovation bud. New leaves are continually formed near the top of the culms with the basal portions being covered by senesced leaf sheaths. These plants may either be tall (up to $2 \mathrm{~m}$ ) and erect, as in Pseudopentameris macrantha, Pentameris macrocalycina and $\boldsymbol{P}$ thuarii, or trailing through the vegetation as in Pentameris squarrosa, Pentaschistis scandens or some of the Ehrharta species. These species do not appear to gain in biomass with successive seasons (probably due to limiting nutrients) but gain in height with a reduction in culm diameter and leaf size. In old plants the leaves may be less than $1 / 4$ the length of those produced in the first post-fire season, but the plant may have doubled in height. Flowering is most frequent in the first year after fire and gradually diminishes in later years.

The group of suffrutescent species belonging to the Villosa and Ramosa groups of Ehrharta are also competitors, mostly at higher altitudes. These are remarkably similar to the Restionaceae, with reduced, caducous leaves and photosynthetic culms.

Members of this specialized group all have the weak type of base and cauline innovation shoots. The leaves vary from sclerophyllous for most of the higher altitude taxa, or caducous (associated with suffrutescent culms) in some species of Ehrharta, to almost mesic in some

TABLE 5. - Distribution of growth form and survival strategy in the competitor Cape grasses. The vegetation types are approximate and follow Moll et al.(1984)

\begin{tabular}{|c|c|c|c|c|}
\hline Species & Base type & $\begin{array}{c}\text { Innovation } \\
\text { buds/shoots }\end{array}$ & Leaf type & Habitat \\
\hline $\begin{array}{l}\text { Ehrharta } \\
\text { ramosa } \\
\text { rehmannii } \\
\text { gigantea }\end{array}$ & \multirow{6}{*}{ weak } & \multirow{4}{*}{$\begin{array}{l}\text { cauline, } \\
\text { tall, erect } \\
\text { plants }\end{array}$} & \multirow[t]{2}{*}{ caducous blades } & Mountain Fynbos \\
\hline $\begin{array}{r}\text { Ehrharta } \\
\text { villosa }\end{array}$ & & & & Lowland Fynbos \\
\hline $\begin{array}{l}\text { Pentameris } \\
\text { dregeana } \\
\text { macrocalycina } \\
\text { longiglumis } \\
\text { obtusifolia } \\
\text { Pentaschistis } \\
\text { colorata } \\
\text { tortuosa }\end{array}$ & & & sclerophyllous & $\begin{array}{c}\text { Mesic } \\
\text { Mountain Fynbos }\end{array}$ \\
\hline $\begin{array}{l}\text { Pentameris } \\
\text { squarrosa } \\
\text { thuarii } \\
\text { Pseudopentameris } \\
\text { macrantha } \\
\text { brachyphylla }\end{array}$ & & & intermediate & $\begin{array}{l}\text { Mesic to wet } \\
\text { Mountain Fynbos, } \\
\text { lower altitudes }\end{array}$ \\
\hline $\begin{array}{c}\text { Ehrharta } \\
\text { setacea } \\
\text { rupestris }\end{array}$ & & $\begin{array}{l}\text { cauline, } \\
\text { short plants }\end{array}$ & sclerophyllous & $\begin{array}{c}\text { Mountain Fynbos, } \\
\text { high altitudes }\end{array}$ \\
\hline $\begin{array}{l}\text { Ehrharta } \\
\text { barbinodis }\end{array}$ & & cauline & intermediate & Succulent Karoo \\
\hline
\end{tabular}


low-altitude competitors. It is not clear how long these species are capable of persisting in unburnt vegetation, as some show signs of senescence. However, this may depend on the density of the local variant of fynbos. It is this group which shows the greatest deal of convergence with the Restionaceae.

\section{Comparison with other biomes}

The spectra of interfire survival strategies found in the Cape are compared in Figure 2 with those of the Grassland and the Savanna Biomes as defined by Gibbs Russell (1985b, 1987c). Direct comparison is difficult, as the enormously different physiography of the different biomes may bias for different growth forms. In addition, the relative frequency of fires in the other biomes suggests that tall and dense interfire vegetation is not a factor, as fire intervals are never as long as 10 years. However, a comparison is still illustrative of how diverse the Cape grasses are in vegetative morphology and ecology in comparison with tropical grasses. From Figure 2 it is abundantly clear that correlated with the extended fire intervals in the fynbos is the occurrence of the "competitor strategy', which is totally absent from the other biomes. Competition avoiders in the other biomes are all hydrophytes, but in the Cape Floristic Region only one species is a hydrophyte, the rest being lithophytes restricted to ledges and crevices. These are, therefore, true vegetation avoiders, compared with the tropical hydrophytes. Geophytes are remarkably common in the Grassland Biomes as well as the fynbos, and the underground storage of photosynthate in grasses may be worthwhile investigating in more detail. Reseeders are understandably more significant in the Savanna Biome than in both fynbos and grassland where rainfall is usually not limiting. However, the relatively large number of exotic pooids in the fynbos tends to obscure this fact.

\section{CONCLUSIONS}

The Poaceae endemic to the fynbos show a range of structural and morphological adaptations which allow them to survive in a variety of niches in the Cape vegetation. Some growth forms allow direct competition with the shrubby Cape Fynbos, while others allow plants to survive the dense interfire vegetation either as seed, as geophytes or as small dormant plants. The models postulated here should contribute to the development of a better understanding of the unique selective forces operative in the fynbos.

The Poaceae in the Cape show a vegetative plasticity not expected from grasses. Unusual growth forms have previously been documented in some arundinoid grasses such as Steyermarkochloa (Davidse \& Ellis 1985) and Arundoclaytonia (Davidse \& Ellis 1987) but, apart from the woody bamboos, extensive cauline branching is basically unknown in the family. The arundinoids do have a wide range in habit, from annuals to reed-grasses like Phragmites (Renvoize 1981). It is therefore not unexpected that the arundinoids have developed the specialized habits to cope with the Cape Fynbos, whereas the indigenous pooids and other subfamilies have been relatively unsuccessful in the Cape. Exotic pooids, on the other hand, are particularly successful in the Cape but, noticeably, not in the natural flora but in areas of physical disturbance.
REFERENCES

ACOCKS, J.P.H. 1988. Veld types of South Africa, 3rd edn. Memoirs of the Botanical Survey of South Africa No. 57.

BARKER, N.P. 1986. The shape and ultrastructure of the caryopsis of Pentameris and Pseudopentameris species (Arundinoideae, Poaceae). Bothalia 16: 65-69.

BOND, P. \& GOLDBLATT, P. 1984. Plants of the Cape Flora. Journal of South African Botany Supplementary volume No. 13

BURNS, W. 1946. Corm and bulb formation in plants, with special reference to the Gramineae. Transactions and Proceedings of the Botanical Society of Edinburgh 24: 316-347.

CAMPBELL, B.M. 1985. A classification of the mountain vegetation of the Fynbos Biome. Memoirs of the Botanical Survey of South Africa No. 50: 1-121.

CHIPPINDALL, L.K.A. 1955. A guide to the identification of grasses in South Africa. In D. Meredith, The grasses and pastures of South Africa: 1-527. Central News Agency, Johannesburg.

CLARK, L.G. \& FISHER, J.B. 1987. Vegetative morphology of grasses: shoots and roots. In T.R. Soderstrom et al., Grass systematics and evolution: 37-45. Smithsonian Institution Press, Washington D.C.

CLAYTON, W.D. \& RENVOIZE, S.A. 1986. Genera graminum. Grasses of the World. Kew Bulletin, Additional Series 13: 1-389.

CONERT, H.J. 1970. Merxmuellera, eine neue Gattung der Gramineen. Senckenbergiana biologica 51: 129-133.

CONERT, H.J. 1971. The genus Danthonia in Africa. Mitteilungen aus der Botanischen Staatssammlung, München 10: 299-308.

COWLING, R.M. 1984. A syntaxonomic and synecological study in the Humansdorp region of the Fynbos Biome. Bothalia 15: 175-227.

DAVIDSE, G. 1988. A revision of Prionanthium (Poaceae: Arundineae). Bothalia 18: 143-153.

DAVIDSE, G. \& ELLIS, R.P. 1984. Steyermarkochloa unifolia, a new genus from Venezuela and Colombia (Poaceae: Arundinoideae: Steyermarkochloeae). Annals of the Missouri Botanical Garden 71: $994-1012$.

DAVIDSE, G. \& ELLIS, R.P. 1987. Arundoclaytonia, a new genus of Steyermarkochloeae (Poaceae: Arundinoideae) from Brazil. Annals of the Missouri Botanical Garden 74: 479-490.

ELLIS, R.P. 1980a. Leaf anatomy of the South African Danthonieae (Poaceae). II. Merxmuellera disticha. Bothalia 13: 185-189.

ELLIS, R.P. 1980b. Leaf anatomy of the South African Danthonieae (Poaceae). III. Merxmuellera stricta. Bothalia 13: 191-198.

ELLIS, R.P. 1982a. Leaf anatomy of the South African Danthonieae (Poaceae).VI. Merxmuellera arundinacea and M. cincta. Bothalia 14: 89-93.

ELLIS, R.P. 1982b. Leaf anatomy of the South African Danthonieae (Poaceae): VII. Merxmuellera dura and M. rangei. Bothalia 14: 95-99.

ELLIS, R.P. 1985a. Leaf anatomy of the South African Danthonieae (Poaceae). X. Pseudopentameris. Bothalia 15: 561-566.

ELLIS, R.P. 1985b. Leaf anatomy of the South African Danthonieae (Poaceae). XI. Pentameris longiglumis and Pentameris sp. nov. Bothalia 15: 567-571.

ELLIS, R.P. 1985c. Leaf anatomy of the South African Danthonieae (Poaceae). XII. Pentameris thuarii. Bothalia 15: 573-578.

ELLIS, R.P. 1985d. Leaf anatomy of the South African Danthonieae (Poaceae). XIII. Pentameris macrocalycina and $P$ obtusifolia. Bothalia 15: 579-585.

ELLIS, R.P. 1986. Leaf anatomy of the South African Danthonieae (Poaceae). XIV. Pentameris dregeana. Bothalia 16: 235-241.

ELLIS, R.P. 1987a. Leaf anatomy of the genus Ehrharia (Poaceae) in southern Africa: the Setacea group. Bothalia 17: 75-89.

ELLIS, R.P. 1987b. Leaf anatomy of the genus Ehrharta (Poaceae) in southern Africa: the Villosa group. Bothalia 17: 195-204.

ELLIS, R.P. 1988a. Leaf anatomy in the South African Danthonieae (Poaceae). XVI. The genus Urochlaena. Bothalia 18: 101-104.

ELLIS, R.P. 1988b. Leaf anatomy of the South African Danthonieae (Poaceae). XVII. The genus Chaetobromus. Bothalia 18: 195209.

ELLIS, R.P. 1989. Leaf anatomy of the South African Danthonieae (Poaceae): XIX. The genus Prionanthium. Bothalia 19: 217-223.

FUGGLE, R.F. \& ASHTON, E.R. 1979. Climate. In J. Day et al., Fynbos ecology, a preliminary synthesis: 7-15. South African National Scientific Programmes Report No. 40.

GIBBS RUSSELL, G.E. 1985a. PRECIS: the National Herbarium's computerized system. South African Journal of Science 81: 62-65.

GIBBS RUSSELL, G.E. 1985b. Analysis of the size and composition of the southern African flora. Bothalia 15: 613-628. 
GIBBS RUSSELL, G.E. 1987a. Taxonomy of the genus Ehrharta (Poaceae) in southern Africa: the Setacea group. Bothalia 17: 67-73.

GIBBS RUSSELL, G.E. 1987b. Taxonomy of the genus Ehrharta (Poaceae) in southern Africa: the Villosa group. Bothalia 17: 191-194.

GIBBS RUSSELL, G.E. 1987c. Preliminary floristic analysis of the major biomes in southern Africa. Bothalia 17: 213-227.

GIBBS RUSSELL, G.E., REID, C., VAN ROOY, J. \& SMOOK, L. 1985. List of southern African plants, edn 2, part 1. Memoirs of the Botanical Survey of South Africa No. 51: 1-152.

GIBBS RUSSELL, G.E. \& ELLIS, R.P. 1987. Species groups in the genus Ehrharta (Poaceae) in southem Africa. Bothalia 17: 51-65.

GIBBS RUSSELL, G.E. \& ELLIS, R.P. 1988. Taxonomy and leaf anatomy of the genus Ehrharta (Poaceae) in southern Africa: the Dura group. Bothalia 18: 165-171.

GOLDBLATT, P. 1978. An analysis of the flora of southern Africa: its characteristics, relationships, and origins. Annals of the Missouri Botanical Garden 65: 369-436.

GOOD, R. 1974. The geography of the flowering plants, edn 4. Longman, London.

GOULD, F. 1968. Grass systematics. McGraw-Hill, New York.

HARBERD, D.J. 1961. Observations on population structure and longevity of Festuca rubra. New Phytologist 60: 184-206.

HARBERD, D.J. 1962. Some observations on natural clones in Festuca ovina. New Phyzologist 61: 85-100.

HODGKINSON, K.C. \& WILLIAMS, O.B. 1983. Adaptation to grazing in forage plants. In J.G. McIvar \& R.A. Bray, Genetic resources of forage plants: 85-100. C.S.I.R.O., East Melbourne.

KRUGER, F.J. 1977. A preliminary account of aerial plant biomass in fynbos communities of the Mediterranean-type climate zone of the Cape Province. Bothalia 12: 301-307.

KRUGER, F.J. 1979. Plant ecology. In J. Day et al., Fynbos ecology: a preliminary synthesis: 88-126. South African National Scientific Programmes Report No. 40.

LINDER, H.P. \& ELLIS, R.P. 1990. A revision of Pentaschistis (Arundineae: Poaceae). Contributions from the Bolus Herbarium 12: $1-124$.
LOVEGROVE, B.G. \& JARVIS, J.U.M. 1986. Co-evolution between mole-rats (Brathyergidae) and a geophyte, Micranthus (Iridaceae). Cimbebasia 8: $79-85$

MANDERS, P.T. \& CUNLIFFE, R.N. 1987. Fynbos plant life histories, population dynamics and species interactions in relation to fire: an overview. In R.M. Cowling et al., Disturbance and dynamics of Fynbos Biome communities: 15-23. South African National Scientific Programmes Report No. 135.

MOLL, E.J., CAMPBELL, B.M., COWLING, R.M., BOSSI, L., JARMAN, M.L. \& BOUCHER, C. 1984. A description of major vegetation categories in and adjacent to the Fynbos Biome. South African National Scientific Programmes Report No. 83

RENVOIZE, S. 1981. The subfamily Arundinoideae and its position in relation to a general classification of the Gramineae. Kew Bulletin 36: 85-102.

ROSHEVITS, R.Y. 1937. Grasses. An introduction to the study of fodder and cereal grasses. Indian National Scientific Documentation Center, New Delhi. Translated in 1980.

RUTHERFORD, M.C. \& WESTFALL, R. 1986. Biomes in southern Africa - an objective categorization. Memoirs of the Botanical Survey of South Africa No. 54: 1-98.

STAPF, O. 1899. Gramineae. Flora capensis, vol. 7, ed. by W.T. Thiselton-Dyer. Lovell Reeve, London.

TAKHTAJAN, A. 1986. Floristic regions of the world. University of California Press, Berkeley.

TAYLOR, H.C., 1978. Capensis. In M.J.A. Werger, Biogeography and ecology of southern Africa. Junk, The Hague.

TSVELEV, N.N. 1976. Grasses of the Soviet Union. Leningrad. English translation published by the Smithsonian Institution Libraries.

VAN WILGEN, B.W. 1987. Fire regimes in the Fynbos Biome. In R.M. Cowling et al., Disturbance and dynamics of Fynbos Biome communities: 6-14. South African National Scientific Programmes Report No. 135.

WATSON, L. \& DALLWITZ, M.J. 1988. Grass genera of the world. Illustrations of characters, descriptions, classification, interactive identification, information retrieval. Australian National University, Canberra. 